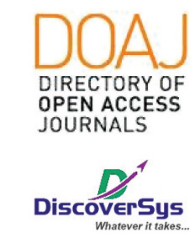

Published by DiscoverSys

\title{
Hubungan faktor bakteriuria dan leukosituria dengan kejadian persalinan Preterm Premature Rupture of Membrane (PPROM) dan Premature Rupture of Membrane (PROM) di RSUD Mangusada, Badung tahun 2018-2019

\author{
I Gusti Ngurah Agung Trisnu Kamajaya ${ }^{1 *}$, I Made Aryana², \\ Anak Agung Ngurah Made Putra Wirawan ${ }^{2}$
}

\section{ABSTRACT}

Background: Preterm labor is one of the most contributors to morbidity and mortality in perinatal and neonatal. Several factors may cause preterm labor with infection as pathophysiology, including urinary tract infection (UTI), to initiate inflammation cascade. This study aims to determine the relationship between bacteriuria and leukocytic factors with the incidence of preterm premature rupture of membrane (PPROM) and premature rupture of membrane (PROM) delivery at Mangusada Hospital, Badung in 2018-2019.

Methods: A cross-sectional observational research toward 92 expectant within PPROM and 92 expectant within PROM was done to know the relation between leukocyturia and bacteriuria with the risk of PPROM and PROM. The research variable involves secondary data from urinalysis of leukocyturia and bacteriuria by flowcytometry Sysmex UX-2000 taken from the patient's registry at maternity room Mangusada Hospital, Badung in 2018-2019. Data were analyzed using SPSS version 17 for Windows.

Results: The study results show leukocyturia in PPROM is about 93.42\% and $6.5 \%$ in PROM, while $71.67 \%$ bacteriuria within PPROM and $28.33 \%$ within PROM. There's no significant relationship between bacteriuria result in PPROM and PROM ( $p=0.247$ ), but there's considerable relation between leukocyturia within PPROM and PROM $(p=0.000)$.

Conclusion: It can be concluded that there's a significant relationship between leukocyturia within PPROM and PROM.

Keywords: PPROM, PROM, Leukocyturia, Bacteriuria

Cite This Article: Kamajaya, I.G.N.A.T., Aryana, I.M., Wirawan, A.A.N.M.P. 2020. Hubungan faktor bakteriuria dan leukosituria dengan kejadian persalinan Preterm Premature Rupture of Membrane (PPROM) dan Premature Rupture of Membrane (PROM) di RSUD Mangusada, Badung tahun 2018-2019. Intisari Sains Medis 11 (3): 1029-1033. D0l: 10.15562/ism.v11i3.781

\section{ABSTRAK}

'Dokter Umum, Rumah Sakit Daerah Mangusada, Badung, Bali, Indonesia

${ }^{2}$ Dokter Spesialis Obstetri dan Ginekologi, Rumah Sakit Daerah Mangusada, Badung, Bali, Indonesia

\section{*Korespondensi:} I Gusti Ngurah Agung Trisnu Kamajaya; Dokter Umum, Rumah Sakit Daerah Mangusada, Badung, Bali, Indonesia; trisnukamajaya@aol.com

Diterima: 03-07-2020 Disetujui: $15-10-2020$ Diterbitkan: 02-11-2020
Latar Belakang: Persalinan preterm merupakan salah satu penyumbang besar morbiditas dan mortalitas perinatal dan neonatal. Berbagai faktor dapat menyebabkan persalinan preterm dengan mekanisme patofisiologi terutama infeksi, salah satunya infeksi saluran kemih (ISK), yang dapat menginisiasi kaskade inflamasi. Penelitian ini bertujuan untuk mengetahui hubungan faktor bakteriuria dan leukosituria dengan kejadian persalinan Preterm Premature Rupture of Membrane (PPROM) DAN Premature Rupture of Membrane (PROM) di RSUD Mangusada, Badung tahun 2018-2019

Metode: Penelitian observational cross-sectional terhadap $92 \mathrm{ibu}$ hamil bersalin dengan PPROM dan 92 ibu dengan PROM dilakukan untuk mengetahui hubungan antara bakteriuria dan leukosituria dengan risiko terjadinya persalinan PPROM dan PROM. Variabel penelitian berupa data sekunder hasil urinanalisa flowcytometry Sysmex UX-2000 (leukosituria dan bakteriuria) diambil dari register pasien di ruang bersalin Rumah Sakit Daerah Mangusada Badung tahun 2018-2019. Data dianalisis dengan SPSS versi 17 untuk Windows.

Hasil: Hasil penelitian menunjukkan leukosituria pada PPROM sebanyak $93.42 \%$ dan $6.5 \%$ pada PROM, sedangkan bakteriuria sebanyak $71.67 \%$ pada PPROM dan $28.33 \%$ pada PROM. Tidak ada hubungan yang bermakna antara kejadian bakteriuria dengan persalinan PPROM dan PROM ( $p=0,247)$. Namun, ditemukan hubungan yang bermakna antara leukosituria dengan persalinan PPROM dan PROM ( $p=0,000)$.

Kesimpulan: Dapat disimpulkan terdapat hubungan signifikan antara leukosituria dengan persalinan PPROM dan PROM. 


\section{PENDAHULUAN}

Prematuritas atau persalinan preterm berhubungan dengan morbiditas dan mortalitas balita. ${ }^{1}$ Bayi yang lahir prematur memiliki kesulitan untuk beradaptasi dengan kehidupan di luar rahim akibat ketidakmatangan sistem organ tubuhnya yang pada akhirnya menimbulkan berbagai komplikasi. ${ }^{1}$ Selain itu, perawatan bayi premature juga membutuhkan teknologi kedokteran canggih dan mahal. ${ }^{1}$

World Health Organization (WHO) menyatakan bahwa persalinan prematur adalah bayi yang lahir pada usia kehamilan $<37$ minggu dari hari pertama haid terakhir. ${ }^{2}$ Persalinan preterm telah menjadi masalah kesehatan global dengan prevalensi sekitar 5- 18\% pada 184 negara, pada negara maju misalnya Eropa angkanya berkisar 5 sampai $11 \%$, di Australia kejadiannya sekitar $7 \%{ }^{2}$ Sementara di Indonesia tahun 2010 angka kejadian kelahiran premature adalah 15,5 per 1000 kelahiran hidup dan menempatkan Indonesia diposisi ke-9 tertinggi dari 184 negara. ${ }^{2,3}$

Persalinan prematur menunjukkan adanya kegagalan mekanisme yang bertanggung jawab untuk mempertahankan kondisi tenang (quiescence) uterus selama kehamilan atau adanya gangguan yang menyebabkan durasi kehamilan lebih singkat. ${ }^{4}$ Berbagai faktor penyebab status prematur ditentukan pula oleh usia kehamilan, diantaranya termasuk infeksi infeksi intrauterine, infeksi sistemik maternal, bakteriuria asimtomatik dan periodontitis maternal. ${ }^{4}$ Infeksi berkaitan dengan peningkatan konsentrasi sitokin proinflamasi Interleukin-1 (IL-1), Tumor Necrotic Factor, IL-6, dan IL-8, prostalglandin, dan Matriks Metalloproteinase (MMP), yang menyebabkan melemahnya ketegangan selaput ketuban. ${ }^{5}$ Saat kondisi ini mendahului peningkatan kontraktilitas uterus dalam 24 - 48 jam, dapat mengakibatkan Premature Rupture of Membrane (PROM) dan Preterm Premature Rupture of Membrane (PPROM) $)^{4,5}$

Infeksi saluran kemih akan memicu perubahan fisik dan kimia urin terutama terjadinya bakteriuria dan leukosituria beserta deteksinya dapat menggunakan carik celup urin atau urinanalisa, selain cost effective dinilai dapat dijadikan metode skrining dan terapi terkait pencegahan terjadinya kejadian infeksi saluran kemih yang merupakan hal yang sangat dibutuhkan untuk menurunkan angka morbiditas dan mortalitas maternal dan neonatal. Disamping itu sampai sekarang masih belum terdapat hubungan yang jelas antara prediktor leukosituria dan bakteriuria dengan kejadian persalinan preterm dengan ketuban pecah dini. Maka dari itu penelitian bertujuan untuk mengetahui hubungan antara bakteriuria dan leukosituria dengan risiko terjadinya persalinan PPROM dan PROM.

\section{METODE}

Jenis penelitian yang dilakukan adalah studi analitik observasional dengan rancangan penelitian (cross-sectional) (potong lintang), untuk menganalisa hubungan bakteriuria dan leukosituria dengan kejadian persalinan preterm. Penelitian ini merupakan penelitian hospital based yang mengambil sumber data sekunder dari rekam medis. Subjek penelitian diambil secara purposive sampling pada 184 pasien yang mengalami persalinan preterm dan aterm di ruang bersalin RS Daerah Mangusada pada tahun 2018 dan 2019. Data dianalisis mulvivariat menggunakan uji regresi linier berganda untuk mengetahui pengaruh antara nilai bakteriuria, nilai leukosituria dengan kejadian persalinan PPROM dan PROM pada ibu hamil. Analisis data penelitian menggunakan piranti lunak SPSS versi 17 untuk Windows.

\section{HASIL}

Sampel penelitian berjumlah 184 orang yang terdiri dari 92 ibu hamil yang mengalami persalinan prematur (umur kehamilan <37 minggu) dengan diagnosis sekunder PPROM dan 92 ibu hamil yang mengalami persalinan cukup umur dengan PROM. Pasien dengan hasil tes mengandung bakteriuria berjumlah 60 orang dimana 71,67\% memiliki diagnosis PPROM, sedangkan sisanya sebanyak 28,33\% memiliki diagnosis PROM (Tabel 1). Pada pasien dengan hasil tes tidak mengandung bakteriuria sebanyak 127 orang, 55,12\% didiagnosis PROM dan sisanya $44,88 \%$ didiagnosis PPROM (Tabel 1). Distribusi frekuensi dari masing-masing variabel yang telah diteliti disajikan dalam Tabel 1. Pasien dengan hasil urninanalisa ditemukannya leukosituria adalah 76 orang dimana 93,42\% memiliki diagnosis PPROM, sedangkan sisanya sebanyak 6,58\% memiliki diagnosis PROM (Tabel 1). Pada pasien dengan hasil laboratorium yang tidak menunjukkan leukosituria sebanyak 111 orang, 73,87\% didiagnosis PROM dan sisanya 26,13\% didiagnosis PPROM (Tabel 1). Sedangkan hasil model regresi logistik individu juga menunjukkan bahwa variabel bakteriuria dan leukositoria memiliki pengaruh yang bermakna terhadap diagnosis persalinan $(\mathrm{p}<0,05)$ (Tabel 2).

Hasil pemodelan regresi logistik biner terhadap umur persalinan dengan uji independensi menunjukkan bahwa Variabel bakteriuria dan leukosituria memiliki hubungan dengan umur persalinan $\left(\mathrm{p}<0,05 ; \mathrm{X}^{2}\right.$ hitung $\left.>\mathrm{X}^{2}(\alpha, \mathrm{df})=3,841\right)$ (Tabel 3). 
Tabel 1. Tabel Kontingensi Umur Persalinan berdasarkan Bakteriuria dan Leukosituria

\begin{tabular}{lcccc}
\hline \multirow{2}{*}{ Variabel } & \multicolumn{2}{c}{ Bakteriuria } & \multicolumn{2}{c}{ Leukosituria } \\
\cline { 2 - 5 } & $\begin{array}{c}\text { Ada } \\
(\mathbf{N}=\mathbf{6 0})\end{array}$ & $\begin{array}{c}\text { Tidak Ada } \\
(\mathbf{N}=\mathbf{1 2 7})\end{array}$ & $\begin{array}{c}\text { Ada } \\
\mathbf{( N = 7 6 )}\end{array}$ & $\begin{array}{c}\text { Tidak Ada } \\
\mathbf{( N = 1 1 1 )}\end{array}$ \\
\hline Diagnosis Persalinan & & & & \\
PROM & $17(28,33)$ & $70(55,12)$ & $5(6,58)$ & $82(73,87)$ \\
PPROM & $43(71,67)$ & $57(44,88)$ & $71(93,42)$ & $29(26,13)$ \\
\hline
\end{tabular}

PROM: Premature Rupture of Membrane; PPROM: Preterm Premature Rupture of Membrane

Tabel 2. Model regresi logistik individu

\begin{tabular}{cccccc}
\hline Variabel & Keterangan & Estimasi B & Wald & p & Exp(B) \\
\hline Bakteriuria & Constant & $-0,205$ & 1,326 & 0,250 & 0,814 \\
& Bakteriuria & 1,133 & 11,278 & 0,001 & 2,106 \\
Leukosituria & Constant & $-1,039$ & 23,146 & 0,000 & 0,354 \\
& Leukosituria & 3,693 & 52,292 & 0,000 & 40,152 \\
\hline
\end{tabular}

Tabel 3. Uji Independensi

\begin{tabular}{lccc}
\hline \multicolumn{1}{c}{ Variabel } & $\mathbf{X}^{\mathbf{2}}$ Hitung & df & $\mathbf{P}$ \\
\hline Bakteriuria & 11,75 & 1 & 0,001 \\
Leukosituria & 82,115 & 1 & 0,000 \\
\hline
\end{tabular}

Tabel 4. Uji Serentak

\begin{tabular}{lccc}
\hline Variabel & Chi-square & df & P \\
\hline Step & 95,429 & 2 & 0,000 \\
Block & 95,429 & 2 & 0,000 \\
Model & 95,429 & 2 & 0,000 \\
\hline
\end{tabular}

bermakna dengan uji serentak (Tabel 4). Sedangkan pada uji parsial ditemukan bahwa variabel yang mempunyai pengaruh bermakna terhadap umur persalinan adalah leukosituria $(\mathrm{p}<0,05)$ (Tabel 5).

Nilai odds ratio untuk seluruh variabel prediktor ditampilkan pada Tabel 6. Pada variabel bakteriuria diperoleh nilai sebesar 1,907 yang berarti bahwa peluang pasien didiagnosis preterm untuk pasien yang tidak mengandung bakteriuria 1,907 kali

Tabel 5. Uji Parsial

\begin{tabular}{lcc}
\hline \multicolumn{1}{c}{ Variabel } & Estimasi B & P \\
\hline Constant & 2,41438 & 0,000 \\
Bakteriuria & $0 ., 678871$ & 0,247 \\
Leukosituria & $-4,04879$ & 0,000 \\
& & \\
\hline
\end{tabular}

Tabel 6. Odds Ratio

\begin{tabular}{lc}
\hline \multicolumn{1}{c}{ Variabel } & Odds Ratio \\
\hline Bakteriuria & 1,97 \\
Leukosituria & 0,02 \\
\hline
\end{tabular}

Regresi logistik secara multivariabel untuk uji serentak menunjukkan bahwa nilai $\mathrm{H}_{0}$ ditolak karena nilai $P$-value untuk model adalah 0.000 yang lebih kecil dari 0,05 (Tabel 4). Sehingga dapat disimpulkan bahwa koefisien $\beta$ berpengaruh secara lebih besar dibandingkan pasien yang mengandung bakteriuria (Tabel 6). Sedangkan untuk variabel leukosituria, peluang pasien yang didiagnosis preterm untuk pasien yang mengandung dan tidak mengandung leukosituria sama besarnya (Tabel 6).

\section{PEMBAHASAN}

Bakteriuria diduga berhubungan erat dengan persalinan prematur. Bakteriuria diperiksa melalui mikroskopis dengan menggunakan urin segar tanpa diputar atau tanpa pewarnaan gram. Dinyatakan positif bila dijumpai satu bakteri per lapangan pandang minyak emersi. ${ }^{5,6}$

Pada penelitian ini ditemukan bakteriuria positif pada pasien dengan persalinan preterm dengan PPROM sebesar $71.67 \%$ dan pada kehamilan aterm dengan PROM sebesar $28.33 \%$. Sedangkan pasien dengan hasil tes tidak mengandung bakteriuria sebanyak 55.12\% didiagnosis PROM dan $44.88 \%$ didiagnosis PPROM. Hasil data tersebut berbanding lurus dengan hasil penelitian Pamungkas AT dengan persentase yang sama antara persalinan preterm 97 ibu hamil dan aterm 103 ibu hamil dan menyatakan ada tidaknya bakteri di urin pada pemeriksaan urinanalisis tidak dapat menjadi patokan prediksi terjadinya persalinan preterm. ${ }^{7}$

Hasil regeresi logistik secara individu pada penelitian ini ditemukan variable bakteriuria ( $p$-value bakteriuria 0,001) dan leukosituria ( $p$-value leukosituria 0,000) diketahui memiliki pengaruh signifikan terhadap kejadian persalinan preterm dengan KPD atau PPROM, namun ketika diuji secara parsial melalui uji regresi logistic secara multivariable bakteriuria diketahui tidak memiliki pengaruh yang signifikan terhadap kejadian preterm dengan PPROM. Penelitian ini sesuai dengan penelitian Fareid MA, yang menjelaskan dalam studinya mengenai kejadian bakteriuria asimptomatik akan lebih berpotensi terjadinya persalinan prematur daripada ibu hamil yang sehat. ${ }^{8}$ Penelitian Golan A juga menyatakan tidak ada perbedaan yang signifikan antara ibu hamil dengan bakteriuria dan ibu hamil dengan non-asymptomatic bakteriuria, ${ }^{9}$ berdasarkan hal diatas aplikasi penelitian ini berbanding terbalik dengan penelitian Sheiner E et al yang menyatakan bahwa asimptomatik bakteriuria meningkatkan kejadian preterm sebanyak 1,8 kali. $^{10}$ Selain itu penelitian oleh Romero R, yang dimana studinya melalukan meta Analisa terhadap 17 studi kohort menunjukkan bakteriuria asimptomatik selama kehamilan secara signifikan meningkatkan tingkat persalinan preterm dan berat badan lahir rendah walaupun pada penelitian ini masih menyertakan variabel pengganggu yang membatasi kekuatan penelitian terkait. $^{6}$ 
Leukosituria pada pemeriksaan urin analisa atau carik celup urin didefinisikan sebagai keadaan ditemukannya leukosit di dalam urin sejumlah $\geq 10 /$ LPB, meski demikian peningkatan leukosit 25/ LPB juga menunjukkan suatu aktivitas kearah patologis. ${ }^{11}$ Pada penelitian ini, hasil urinanalisa ditemukan dominan leukosituria pada PPROM dan tidak ditemukan leukosituria dominan pada pasien dengan PROM. Hal ini berkaitan dengan penelitian oleh Mochamad M mengenai, dimana dinyatakan dari $18 \mathrm{ibu}$ dengan persalinan preterm, $50 \%$ didapati leukosituria pada urinanalisa dan sisanya tidak didapati urinanalisa, dan hanya 1 pasien dengan persalinan aterm yang didapati leukosituria. ${ }^{12}$

Setelah dilakukan uji independensi terkait variabel prediktor leukosituria terhadap persalinan preterm dengan KPD atau PPROM diketahui bahwa variabel leukosituria memiliki hubungan dengan kejadian PPROM hal ini ditunjukkan oleh nilai P-value yang kurang dari 0,05 atau nilai $\mathrm{X}^{2}$ hitung lebih besar dari 3,841. Untuk mengetahui signifikansi dari hubungan variabel leukosituria dilakukan regresi logistik baik secara individu maupun secara multivariable, didapatkan signifikan dengan $\mathrm{p}$ value untuk model adalah 0.00 yang lebih kecil dari 0,05 sehingga keputusan yang diperoleh adalah tolak $\mathrm{H}_{0}$. Hal ini konsisten dengan hasil penelitian oleh Mochamad M, dimana didapat hubungan yang sangat signifikan antara insiden PPROM dengan leukosituria, ${ }^{12}$ selain itu penelitian ini juga berbanding lurus dengan studi oleh Nuada IN et al, yang menyatakan ibu hamil dengan leukosit $\geq 5 / \mathrm{LPB}$ memiliki risiko 7.67 kali lebih besar terjadinya ancaman persalinan preterm. ${ }^{13}$ Studi lain oleh Pamungkas AT menemukan adanya hubungan yang bermakna $(\mathrm{p}=0,008)$ antara leukosituria dengan persalinan preterm. ${ }^{7}$

Hal tersebut berkaitan dengan teori dimana infeksi yang menginisiasi kaskade inflamasi (IL1 $\beta$, IL-6, IL-8, TNF $\alpha$ ) yang mengakibatkan degradasi MMP dengan TMP (tissue inhibitor of matrix metalloproteinase). ${ }^{5}$ Protease apoptosis akan berjalan akibat teraktivasinya kaskade inflamasi ini, selain itu adanya protease bakteri akan meningkatkan produksi glukokortikoid yang menyebabkan penurunan kekuatan kolagen selaput amnion. ${ }^{5}$ Ini semua akan menyababkan terjadinya KPD.

Infeksi saluran kemih adalah komplikasi yang sering ditemukan pada kehamilan, dapat diklasifikasikan menjadi infeksi saluran kemih atas (pielonefritis) dan bawah (sistitis dan bakteriuria asimptomatik). Walaupun prevalensi sistitis dan bakteriuria asimptomatik sama pada wanita hamil dan tidak hamil, infeksi saluran kemih bawah menjadi faktor risiko yang besar untuk terjadinya pielonefritis pada kehamilan. Peningkatan risiko pielonefritis berkaitan dengan perubahan secara sekunder dari anatomi dan fisiologi pada kehamilan. ${ }^{14}$ Berdasarkan penelitian oleh Fareid MA disebutkan prevalensi infeksi saluran kemih pada wanita hamil menyebabkan komplikasi yang serius seperti penyakit hipertensi, BBLR, kelahiran prematur dan anemia dimana hal ini akan menyebabkan tingginya morbiditas ibu dan janin. ${ }^{8}$ Begitupula dengan rendahnya serum katalase yang memiliki kaitan dengan infeksi diketahui berhubungan erat dengan kejadian kelahiran preterm. ${ }^{15}$

Berdasarkan pemodelan regresi logistic biner terhadap umur persalinan ditemukan bawha terdapat hubungan antara variabel predictor bakteriuria dan leukosituria dengan persalinan preterm dengan KPD dimana pada pengujian menggunakan chi-square ditemukan ada hubungan antara bakteriuria $(\mathrm{p}=0,001$ dan leukosituria $(\mathrm{p}=0,000)$ hal tersebut kemudian dibuktikan melalui regresi logistic secara multivariable untuk mengetahui efek faktor bakteriuria dan leukosituria ketika dilakukan uji serentak apakah akan secara signifikan berpengaruh terhadap usia persalinan. diperoleh bahwa tolak H0 karena nilai P-value untuk model adalah 0,000 yang lebih kecil dari 0,05. Dapat disimpulkan bahwa koefisien $\beta$ berpengrauh signifikan secara serentak. Hasil penelitian ini berbanding lurus dengan penelitian Jannah $\mathrm{M}$ di RSUD Dr. Adjidarmo Lebak Banten periode Januari hingga Desember 2010 dimana menunjukkan terdapat hubungan antara infeksi saluran kemih pada wanita hamil dengan kejadian prematur dengan $\mathrm{p}=0,022 \quad(\mathrm{p}<0,05) .{ }^{16}$ Hal ini dijelaskan pula oleh Dimetry SR bahwa ada hubungan antara ISK dan persalinan preterm $(p$-value $=0.001)$ dan probabilitas persalinan preterm bagi ibu dan BBLR pada bayi akan meningkat jelas pada orang dengan riwayat ISK. ${ }^{17}$ Penelitian oleh Verma I et al juga menyatakan bahwa ibu yang mengalami persalinan preterm memiliki 2,67 kali insiden riwayat ISK dibandingkan dengan yang tidak. ${ }^{18}$ Studi observasional ini juga mirip dengan hasil dari studi oleh Jain $\mathrm{V}$ et al yang melaporkan kejadian infeksi saluran kemih ditemukan pada pasien dengan persalinan preterm sebanyak $20,34 \%$ dan dari penelitian oleh McPheters et al yang melaporkan sebanyak $17,1 \%$ riwayat infeksi saluran kemih pada persalinan preterm. ${ }^{19,20}$

\section{KETERBATASAN PENELITIAN}

Data utama yang digunakan merupakan data sekunder serta sifat penelitian ini adalah penelitian berbasis retrospektif, sehingga tidak didapatkan hasil yang pasti bakteri yang menyebabkan 
bakteriuria. Penelitian ini juga hanya menggunakan hasil urinanalisa sebagai hasil laboratorium utamanya, dimana diketahui bakteriuria sesuai teori diatas umunya menggunakan kultur urin sebagai data sampel utama dengan spesifisitas dan sensitifitas yang lebih dominan dibandingkan urinalisa. Selain itu pasien dengan KPD tidak selalu rutin dilakukan pemeriksaan urinalisa beserta banyaknya komorbiditas pasien dengan persalinan preterm yang masuk dalam kriteria eksklusi sehingga banyak sampel pasien yang di ekslusi dari penelitian ini.

\section{SIMPULAN}

Secara garis besar dapat disimpulkan bahwa penelitian ini menunjukkan terdapat hubungan yang bermakna antara leukosituria dengan angka insiden terjadinya persalinan PPROM dan PROM.

\section{KONFLIK KEPENTINGAN}

Penulis menyatakan bahwa tidak terdapat konflik kepentingan dalam penulisan laporan penelitian ini.

\section{PERSETUJUAN ETIK}

Penelitian ini telah mendapatkan persetujuan etik dari Komisi etik penelitian Kesehatan Rumah Sakit Daerah Mangusada Kabupaten Badung dengan Nomor:800/13160/RSD/2019 sebelum penelitian berjalan.

\section{PENDANAAN}

Penelitian ini menggunakan pendaan secara pribadi tanpa melibatkan pihak sponsor atau sumber pendanaan lainnya.

\section{KONTRIBUSI PENULIS}

Seluruh penulis berkontribusi terhadap penulisan laporan penelitian ini baik dari penyusunan kerangka konsep, pengumpulan data, analisis data penelitian, hingga interpretasi laporan penelitian dalam bentuk publikasi ilmiah.

\section{DAFTAR PUSTAKA}

1. Glass HC, Costarino AT, Stayer SA, Brett CM, Cladis F, Davis PJ. Outcomes for extremely premature infants. Anesth Analg. 2015;120(6):1337-1351.

2. Quinn JA, Munoz FM, Gonik B, Frau L, Cutland C, Mallett-Moore T, et al. Preterm birth: Case definition \& guidelines for data collection, analysis, and presentation of immunisation safety data. Vaccine. 2016;34(49):6047-6056.

3. Purisch SE, Gyamfi-Bannerman C. Epidemiology of preterm birth. Semin Perinatol. 2017;41(7):387-391.
4. Stewart A, Graham E. Preterm birth: An overview of risk factors and obstetrical management. Dev Disabil Res Rev. 2010;16(4):285-288.

5. Nadeau HC, Subramaniam A, Andrews WW. Infection and preterm birth. Semin Fetal Neonatal Med. 2016;21(2):100105.

6. Romero R, Oyarzun E, Mazor M, Sirtori M, Hobbins JC, Bracken M. Meta-analysis of the relationship between asymptomatic bacteriuria and preterm delivery/low birth weight. Obstet Gynecol. 1989;73(4):576-582.

7. Pamungkas AT. Perbandingan Angka Kejadian Bakteriuria dan Leukosituria antara Persalinan Aterm dan Preterm Studi kasus di RSUP Dr. Kariadi Periode 2013 [Skripsi]. Semarang: Balai Penerbit Universitas Diponegoro. 2014.

8. Fareid MA. Frequency and Susceptibility Profile of Bacteria Causing Urinary Tract Infections among Women. New York Science Journal. 2012;5(2):72.

9. Golan A, Wexler S, Amit A, Gordon D, David MP. Asymptomatic bacteriuria in normal and highrisk pregnancy. Eur J Obstet Gynecol Reprod Biol. 1989;33(2):101-108.

10. Sheiner E, Mazor-Drey E, Levy A. Asymptomatic bacteriuria during pregnancy. J Matern Fetal Neonatal Med. 2009;22(5):423-427.

11. Houston IB. Measurement of pyuria in urinary tract infections. Arch Dis Child. 1969;44(236):480-482.

12. Mochamad M, Ayu PK., The Relationship of Leukocyturia on The Incidence of Prominent Rupture of The Membrane in Preterm Pregnancy at The General Hospital of The University of Muhammadiyah Malang. Jurnal Saintika Medika. 2019;15(2):139-145.

13. Nuada IN, Karkata MK, Suastika K. Risiko Partus Prematurus Iminen pada Kehamilan dengan Infeksi Saluran Kemih. Cermin Dunia Kedokteran. 2004;145:2630.

14. Gravett MG, Rubens CE, Nunes TM; GAPPS Review Group. Global report on preterm birth and stillbirth (2 of 7): discovery science. BMC Pregnancy Childbirth. 2010;10 Suppl 1(Suppl 1):S2.

15. Negara IKS, Surya IGP, Sanjaya H, Anantasika AAN, Mahardika IM. Lower Serum Catalase Level is Associated with Preterm Labor among Pregnant Women at Sanglah Hospital Denpasar, Bali-Indonesia. Bali Medical Journal. 2016;5(3):404-407.

16. Jannah M. Hubungan Infeksi Saluran Kemih pada Ibu Hamil terhadap Partus Prematurus di RSUD Dr. Adjidarmo Lebak Banten Periode Januari hingga Desember 2010 [Skripsi]. Banten: Universitas Islam Negeri Syarif Hidayatullah. 2011.

17. Dimetry SR, El-Tokhy HM, Abdo NM, Ebrahim MA, Eissa M. Urinary tract infection and adverse outcome of pregnancy. J Egypt Public Health Assoc. 2007;82(3-4):203218.

18. Verma I, Avasthi K, Berry V. Urogenital infections as a risk factor for preterm labor: a hospital-based case-control study. J Obstet Gynaecol India. 2014;64(4):274-278.

19. Jain V, Das V, Agarwal A, Pandey A. Asymptomatic bacteriuria \& obstetric outcome following treatment in early versus late pregnancy in north Indian women. Indian J Med Res. 2013;137(4):753-758.

20. McPheeters ML, Miller WC, Hartmann KE, et al. The epidemiology of threatened preterm labor: a prospective cohort study. Am J Obstet Gynecol. 2005;192(4):13251330 .

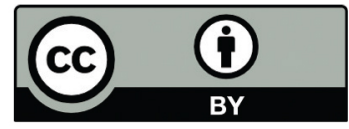

This work is licensed under a Creative Commons Attribution 